\title{
KOMUNIKASI PARTISIPATIF DALAM PROSES PEMBAGUNAN BENDUNGAN MATENGGENG KABUPATEN CILACAP JAWA TENGAH
}

\author{
Waluyo Handoko \\ FISIP- Universitas Jenderal Soedirman, J1. Prof. Dr. H. Bunyamin No 993 Purwokerto Jawa Tengah 53122. Tlp \\ (0281) 635292-4.HP.081391350428.E-mail:whandoko 18@yahoo.com.
}

Adhi Iman Sulaiman

FISIP- Universitas Jenderal Soedirman, Jl. Prof. Dr. H. Bunyamin No 993 Purwokerto Jawa Tengah 53122. Tlp (0281) 635292-4. E-mail: adhi_iman@yahoo.com.

\section{Andi Ali Said Akbar}

FISIP- Universitas Jenderal Soedirman, J1. Prof. Dr. H. Bunyamin No 993 Purwokerto Jawa Tengah 53122. Tlp (0281) 635292-4. E-mail: alisaid pol@yahoo.co.id.

Naskah diterima tanggal 14 Oktober 2014, direvisi tanggal 22 November 2014, disetujui tanggal 26 November 2014

\section{PARTICIPATORY COMMUNICATION IN DEVELOPMENT PROCESS OF MATENGGENG DAMS CILACAP DISTRICT CENTRAL JAVA}

\begin{abstract}
The construction process of Matenggeng Dams is still have problem such as no dialogue or renegotiation to create a mutual agreement between the government and Dayeuhluhur society. This research aims to identify, analyze and design the model of participatory development communication in the construction process of Matenggeng Dams at Dayeuhluhur subdistrict Cilacap District, Central Java Province. This research used qualitative method with case study. Data Collection through interviews, observation, analysis of documentation and focus group discussions (FGD). The results showed: (1) People have known for a long time about the discourse of Matenggeng Dams construction through interpersonal communication from the parents. (2) There is still no agreement about compensation between the community and the government. (3) The community agree and have learned the benefits of dams and willing to dialogue again to achieve an agreement of compensation for the land and productive trees. The implication, the public will continue to feel anxious for certainty the future of people's lives, if there is no certainty continuation the development of the Matenggeng dams.
\end{abstract}

Keywords: participatory development, community, dialogue.

\begin{abstract}
Abstrak
Proses pembangunan bendungan Matenggeng masih memiliki permasalahan yaitu belum ada dialog atau negosiasi ulang untuk menghasilkan kesepakatan bersama antara pemerintah dengan masyarakat Dayeuhluhur. Penelitian ini bertujuan mengidentifikasi, menganalisis, dan merancang model komunikasi pembangunan partisipatif dalam proses pembangunan Bendungan Matenggeng, Kecamatan Dayeuhluhur, Kabupaten Cilacap, Provinsi Jawa Tengah. Penelitian ini menggunakan metode kualitatif dengan studi kasus. Pengumpulan data dengan wawancara, observasi, dan analisis dokumentasi serta focus group discussion (FGD). Hasil penelitian
\end{abstract}


menunjukkan: (1) Masyarakat sudah mengetahui sejak lama tentang wacana pembangunan Bendungan Matenggeng melalui komunikasi interpersonal dari orang tua secara turun termurun. (2) Masih belum ada kesepakatan ganti untung antara masyarakat dengan pihak pemerintah. (3) Pihak masyarakat sangat setuju dan mengetahui manfaat dibangunnya bendungan serta bersedia berdialog kembali untuk menyepakati ganti untung lahan tanah dan pohon produktif. Implikasinya, masyarakat akan terus merasa resah akan kepastian masa depan kehidupan masyarakat, jika belum ada kepastian kelanjutan pembangunan Bendungan Matenggeng.

Kata kunci: pembangunan partisipatif, masyarakat, dialog.

\section{PENDAHULUAN}

Berdasarkan Masterplan Percepatan dan Perluasan Pembangunan Ekonomi Indonesia (MP3EI) 2011-2025, salah satunya akan dilaksanakan pembangunan Bendungan Matenggeng pada tahun 2013-2018. Menurut Kepala Balai Besar Wilayah Sungai (BBWS) Citanduy, Soekotjo Tri Sulistyo bahwa latar belakang rencana pembangunan Bendungan Matenggeng, dalam rangka mengembangkan potensi sumber daya air di daerah aliran sungai (DAS) Citanduy dan sungai Cijolang yang akan mencapai 2.222,70 hektar. Distribusi luas daerah rencana terendam Bendungan Matenggeng untuk Kabupaten Cilacap, Provinsi Jawa Tengah seluas 1.135,07 hektar atau sebesar 57,60 persen yakni di Kecamatan Dayeuhluhur. Sedang untuk wilayah Jawa Barat meliputi Kecamatan Cilebak, Kabupaten Kuningan seluas 41, 26 hektar atau 2,09 persen, Kecamatan Tambaksari, Kabupaten Ciamis seluas 776,32 hektar atau 33,40 persen dan Kecamatan Rancah, Kabupaten Ciamis seluas 17,93 hektar atau sebesar 0,91 persen. Sementara jumlah kepala keluarga (KK) di daerah rencana terendam Bendungan Matenggeng mencapai $2152 \mathrm{KK}$ terdiri dari 1.305 KK di Kecamatan Dayeuhluhur, Kabupaten Cilacap, Provinsi Jawa Tengah, 781 KK di Kecamatan Tambaksari, Kabupaten Ciamis, 33 KK di Kecamatan Rancah, Kabupaten Ciamis dan 33 KK di Kecamatan Cilebak, Kabupaten Kuningan Provinsi Jawa Barat (Soekotjo, 2013a).

Bendungan Matenggeng sebagai solusi persoalan air dan banjir di wilayah Jawa Tengah di Kabupaten Cilacap Barat serta sebagian wilayah Jawa Barat, yang sudah digagas sejak 1969 lalu, bahkan konsultan dari Amerika Serikat telah dua kali melaksanakan survei terhadap rencana pembangunan Bendungan Matenggeng yakni pada 1969 dan 1989, namun belum ada kelanjutan. Akhirnya direalisasikan kembali dengan masuk pada Masterplan P3EI 20112025 (2011) sedang dirancang perjanjian kerjasama antara Kabupaten Cilacap, Provinsi Jawa Tengah, Kabupaten Ciamis dan Kuningan, Provinsi Jawa Barat terkait komitmen pembebasan lahan dan pembangian (sharing) pendanaan anggaran. Proses pembangunan bendungan, menurut Kepala Balai Besar Wilayah Sungai (BBWS) Citanduy, Soekotjo Tri Sulistyo, dilakukan dengan tahapan pembangunanya yaitu: tahun 2013 ditargetkan dapat menyelesaikan pembangunan akses jalan masuk, tahun 2014 pembebasan lahan bendungan dan tahun 2015 pembangunan konstruksi (Soekotjo, 2013b).

Adapun hasil penelitian dan kajian menjelasakan tujuan dan manfaat pembangunan Bendungan Matenggeng, yang dibahas dalam Rapat Tim Teknis Penilai analisis mengenai dampak lingkungan (AMDAL) Pusat Rencana Pembangunan Bendungan Matenggeng di Wilayah Kabupaten Cilacap, Provinsi Jawa Tengah dan Kabupaten Ciamis Provinsi Jawa Barat pada Selasa, 19 Februari 2013. Rapat tersebut dipimpin oleh Asisten Deputi Kajian Dampak Lingkungan, Kementerian Lingkungan Hidup, dengan peserta dari jajaran pemerintahan sebagai stakeholders dari Kabupaten Cilacap dan Kabupaten Ciamis dan Kabupaten Kuningan, yang menghasilkan manfaat sebagai berikut: (1) Untuk penyediaan air irigasi pertanian di daerah hilir dan menjamin tersedianya air irigasi untuk lahan seluas 27.927 hektar di empat kabupaten/kota, yaitu Kabupaten Cilacap, 
Kabupaten Ciamis, Kabupaten Kuningan, dan Kota Banjar; (2) Menyediakan pasokan air baku, terutama pada musim kemarau untuk pengembangan air baku di empat kecamatan di Jawa Barat dan Jawa Tengah; (3) Mengurangi besarnya banjir ke bagian hilir sebesar $65 \%$. Adapun manfaat utamanya bagi masyarakat atau penerima manfaat (benefeciaries) di lingkungan sekitar Bendungan, terutama Kabupaten Cilacap, Kabupaten Ciamis, Kabupaten Kuningan, dan Kota Banjar dalam bentuk ketersediaan air baku, pengairan (irigasi) dan reduksi debit banjir (Kurniawan, 2013).

Proses pembangunan Bendungan Matenggeng akan memiliki konsekuensi dengan adanya pemindahan atau relokasi dengan segala penghidupan masyarakat di desa, baik secara fisik yaitu tempat tinggal dan semua fasilitas umum serta infrastuktur, maupun non fisik yaitu secara psikologis dan sosiologis.

Proses pembangunan Bendungan Matenggeng dapat ditelaah secara teoretis, sebagaimana menurut Alam (2012), pembangunan yang dilaksanakan harus dapat mewujudkan kesejahteraan rakyat dan ketahanan budaya harus, menjadi agenda pembangunan yang penting dan strategis dengan diikuti penetapan atau kebijakan yang efektif.

Melakukan proses pembangunan kembali beserta penghidupan masyarakat khususnya di desa, perlu memerhatikan perinsip-perinsip sebagaimana menurut Adisasmita (2006), yaitu: (1) Transparansi (keterbukaan); (2) Partisipatif; (3) Dapat dinikmati masyarakat; (4) Dapat dipertanggungjawabkan (akuntabilitas); (5) Berkelanjutan (sustainable). Penegasannya pada pelibatan masyarakat yang seharusnya diajak untuk ikut menentukan visi (wawasan) pembangunan masa depan yang lebih baik menuju kemakmuran yang lebih tinggi. Hal tersebut dilakukan dengan pendekatan multisektoral (holistik) dan partispatif berlandaskan pada semangat kemandirian, berwawasan lingkungan dan berkelanjutan dengan pemanfaatan sumberdaya yang serasi dan selaras serta sinergis.
Pihak masyarakat di lokasi pembangunan Bendungan Matenggeng yang mengalami dampak risiko fisik dan non fisik tersebut, harus diakomodir aspirasinya (keinginan dan harapannya) dengan pendekatan yang humanis dan dialogis. Supaya dapat menghindari atau mengantisipasi sejak dini tentang konflik antara masyarakat dengan masyarakat atau konflik horisontal dan konflik vertikal antara masyarakat dengan pihak pemerintah. Hal tersebut sebagaimana menurut Adi (2003) tidak jarang adanya kelompok-kelompok dalam komunitas yang melakukan penolakan terhadap "pembaharuan" (inovasi) yang tidak menginginkan perubahan (pembangunan).

Pembangunan adalah usaha-usaha yang secara sistematis terarah pada pengadaan perubahan yang senantiasa membawa konflik, maka semestinya setiap usaha pembangunan mencakup pula antisipasi atau pengelolaan konflik (Moeliono et al. 2003).

Diperlukan suatu usaha bersama dari semua pihak, baik pemerintah, wakil rakyat, masyarakat sendiri, termasuk perguruan tinggi secara komprehensif untuk mengantisipasi konsekuensi atau risiko dan permasalahan yang akan terjadi dalam proses pembangunan Bendungan Matenggeng secara partisipatif. Sehingga perlu dan pentingnya dilakukan penelitian komunikasi pembangunan partisipatif sebagai bentuk kontribusi nyata dari perguruan tinggi bagi proses pembangunan Bendungan Matenggeng. Adapun lokasi penelitian untuk tahap pertama di wilayah yang paling besar terendam daerahnya, seluas 1.135,07 hektar atau sebesar 57,60 persen dari luas Bendungan Matenggeng, yaitu desa-desa di Kecamatan Dayeuhluhur yang meliputi Desa Dayeuhluhur, Matenggeng, Ciwalen, Bolang, Kutaagung, Datar, Cijeruk dan Bingkeng Kabupaten Cilacap, Provinsi Jawa Tengah (Soekatjo, 2013).

Pada tahap pertama pelaksanaan penelitian difokuskan pada dua desa saja yaitu Desa Dayeuhluhur dan Desa Matenggeng. Pertimbangan memilih Desa Dayeuhluhur adalah sebagai ibukota Kecamatan Dayeuhluhur dan Desa Matenggeng sebagai lokasi pusat 
pembangunan bendungan, sehingga dinamakan Bendungan Matenggeng. Berdasarkan hal tersebut dapat dibuat rumusan masalah yaitu bagaimana komunikasi pembangunan partisipatif masyarakat dalam proses pembangunan Bendungan Matenggeng di Kecamatan Dayeuhluhur, Kabupaten Cilacap, Provinsi Jawa Tengah? Tujuan penelitian untuk mengidentifikasi, menganalisis, dan merancang model komunikasi pembangunan partisipatif dalam proses pembangunan Bendungan Matenggeng. Hasil penelitian memberikan manfaat akademis untuk pengembangan ilmu pengetahuan dan penelitian lanjutan. Manfaat praktis dapat memberikan rekomendasi bagi stakeholders dalam perumusan dan pelaksanaan kebijakan publik.

\section{LANDASAN KONSEP}

Beberapa tinjauan literatur tentang komunikasi pembangunan partisipatif, yang relevan dengan penelitian ini. Menurut Mardikanto (2010), komunikasi pembangunan dapat diartikan sebagai proses interaksi seluruh pemangku kepentingan untuk tumbuhnya kesadaran, kemauan, dan kemampuan menggerakkan serta mengembangkan partisipasi mereka dalam proses perubahan terencana demi perbaikan mutu hidup segenap warga masyarakat secara berkesinambungan, melalui optimalisasi sumber daya yang dapat dimanfaatkan, dengan menggunakan teknologi atau menerapkan inovasi yang sudah terpilih.

Komunikasi dipandang sebagai motor penggerak untuk pelestarian budaya, suatu perubahan, proyeksi, dan perpaduan semua perspektif lintas-budaya yang dibutuhkan untuk membentuk proses pembangunan dan struktur masyarakat serta budaya di masa depan (Nair dan White, 2004).

Menurut McPhail (2009), komunikasi merupakan hal yang sangat mendasar atau fundamental untuk membantu masyarakat mengubah komunitasnya, di mana mereka tinggal, khususnya strategi komunikasi yang mampu menginfromasikan dan memperkuat kekuatan suara (aspirasi atau opini) yang dipertaruhkan terhadap hambatan struktural untuk mencapai tujuan. Maka upaya komunikasi dapat mencakup penjelasan tentang berbagai modus masyarakat setempat yang menggunakan komunikasi untuk membuat makna mengenai pengalaman, tempat tinggal, sejarah, identitas, sumber daya, dan keterlibatannya di dunia global (Porras dan Steeves, 2009).

Dasgupta (2009), mengutip pendapat Mefalopulos, bahwa komunikasi untuk pembangunan yang menghasilkan partisipasi, dialog, dan penyebaran pengetahuan itu penting. Komunikasi juga dapat membantu pembangunan dengan mendukung dan mengadopsi model yang benar-benar membutuhkan dialog dari kolaborasi antara semua pemangku kepentingan dan benarbenar membutuhkan berbagai pengetahuan sebagai bentuk terbaik dari pendidikan bersama.

Penting dan strategisnya peran komunikasi yang tidak bisa dipisahkan dalam pembangunan, sebagaimana menurut Lubis (2010) bahwa komunikasi berperan untuk memfasilitasi penemuan (invention) dan menyebarkan inovasi ke sistem sosial yang lebih luas. Komunikasi sangat bermanfaat untuk pembangunan. Penerapan komunikasi untuk pembangunan dan perubahan sosial disebut komunikasi pembangunan (Development Communication).

Mikkelsen (2011) mengutip pendapat Jamieson, bahwa pembangunan partisipatif mengidentifikasikan adanya dua perspektif yaitu: (1) Pelibatan masyarakat setempat dalam pemilihan, perancangan, perencanaan, dan pelaksanaan program yang akan menentukan mereka, sehingga persepsi, sikap, pemikiran, dan nilai-nilai serta ilmu pengetahuan ikut dipertimbangkan secara penuh; (2) Membuat umpan balik (feedback) yang pada hakikatnya merupakan bagian tak terlepaskan dari kegiatan pembangunan.

Hasim dan Remiswal (2009) mengutip pendapat J. Pretty et al. bahwa pendekatan pembangunan partisipasi khususnya untuk penguatan kelembagaan masyarakat, memiliki proses sebagai berikut: (1) Passive participation. (2) Participation in information 
giving. (3) Participation by consultation. (4) Participation for material incentives. (5) Functional participation. (6) Interactive participation. (7) Self mobilization. Adapun tahapan partisipasi untuk pengembangan komunitas dapat dilihat pada gambar 1 .

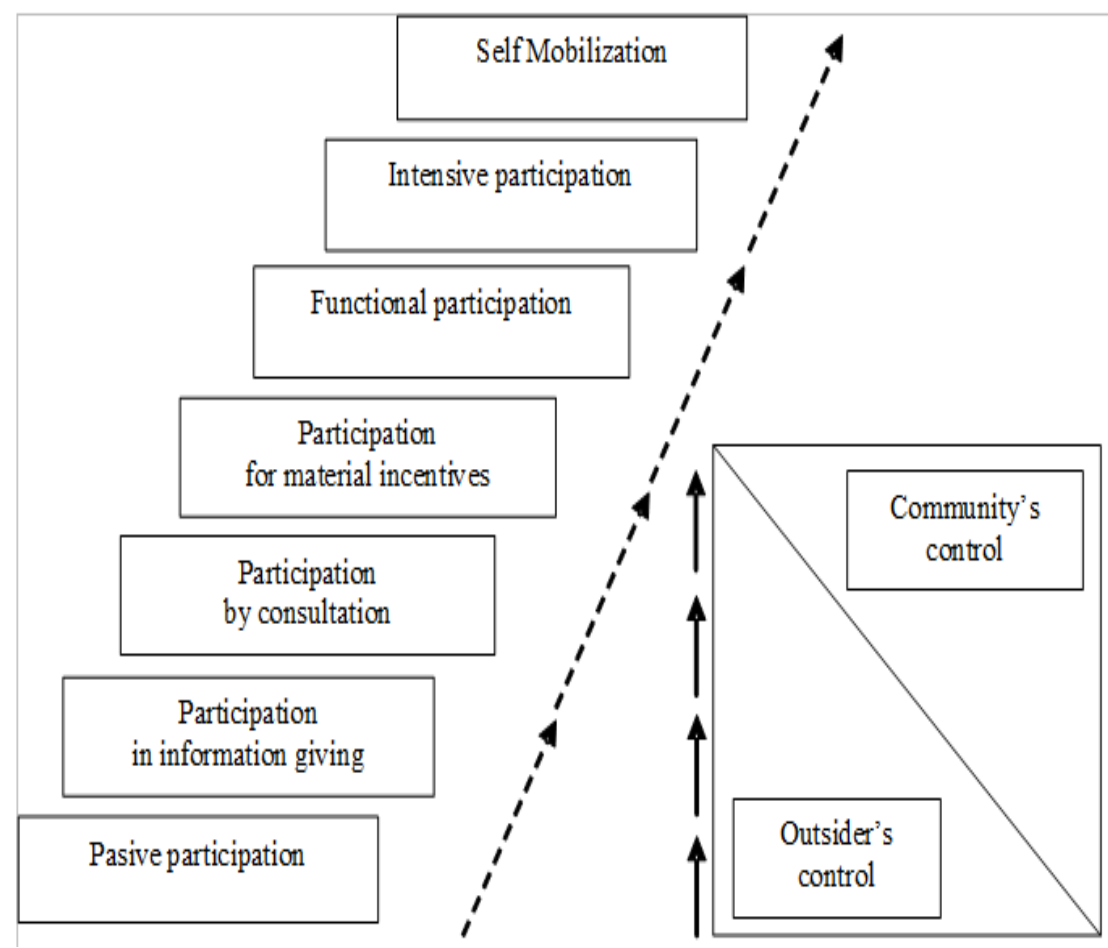

Sumber: J. Pretty et al (dalam Hasim dan Remiswal 2009).

\section{Gambar 1}

Tipologi Partisipasi dalam Pengembangan Komunitas

\section{METODE PENELITIAN}

Menggunakan metode penelitian kualitatif studi kasus yang memelajari secara mendalam fenomena dari realitas dan interaksi dalam lingkungan suatu unit sosial seperti individu, kelembagaan, dan masyarakat (Subyantoro dan Suwarto 2007). Pengumpulan data dengan wawancara, observasi, dan analisis dokumentasi serta focus group discussion (FGD). Menggunakan penentuan informan dengan purposif sampling (Adisasmita, 2006). Adapun informan yang dipilih adalah para pemangku kepentingan (stakeholders) di tingkat desa. (1) Desa Dayeuhluhur informannya yaitu Agus Carwoto, Wartom Suwanto, Hartini, Nenti, Neska, Warkum, Sawabi Ikhsan, Dede Hudaepah, Atwar Badarusalam, Sari Hayati, Ahmad Tasripin, Wawan Karwan, Sarsa Supriyanto, Komarudin, Amir Syarifudin, Taryat, Ruswanto, Iing Supriyatna, Karseno,
Muhammad Darojat, Sunandar Najarudin Latif, Rahmat Budiyono, dan Dahlan. (2) Desa Matenggeng informannya yaitu Arsim, Lili, Artu, Tabir, Caso, Darum, Kasa Raharja, Karlem, Upang, Karsa, Basuki, Darsih, Suhedi, Rukim, Saefudin, Tursino, dan Rusan Supriadi

Lokasi penelitian tahap pertama ini difokuskan pada dua desa dengan pertimbangan, yaitu Desa Dayeuhluhur adalah sebagai ibukota Kecamatan Dayeuhluhur dan Desa Matenggeng sebagai lokasi pusat pembangunan bendungan, sehingga dinamakan Bendungan Matenggeng. Penelitian ini menggunakan analisis data model interaktif dari Miles dan Huberman (2007) yang terdiri dari tiga hal utama: (1) Reduksi data, merupakan proses pemilihan, pemusatan, penyederhanaan, dan klasifikasi data yang muncul dari catatan-catatan di lapangan, yang berlangsung secara terusmenerus selama penelitian; (2) Penyajian data 
adalah kumpulan informasi yang tersusun dan memberi kemungkinan adanya penarikan kesimpulan dan pengambilan tindakan; (3) Penarikan kesimpulan atau verifikasi, mulai dari mencari, mencatat keteraturan, pola-pola, penjelasan, konfigurasi yang utuh, tinjauan ulang pada catatan lapangan, dan tukar pikiran di antara teman sejawat untuk mengembangkan kesepakatan intersubjektif.

\section{HASIL PENELITIAN DAN PEMBAHASAN}

Tahapan proses penelitian ini adalah sebagai berikut: (1) Studi pendahuluan dengan kajian literatur terhadap hasil riset, jurnal, buku teks, dan media massa. Kemudian melakukan diskusi ilmiah dengan teman sejawat dan praktisi serta menyusun proposal penelitian antara bulan Agustus 2013 sampai Maret 2014. (2) Melakukan pembukaan akses, pendekatan, observasi ke lapangan dan melaksanakan penelitian di lokasi antara bulan Juni dan Juli 2014. (3) Melakukan FGD dengan praktisi dan ahli, pengolahan dan analisis data, serta menyusun laporan penelitian pada Juli sampai Oktober 2014.

\section{Proses Sosialisasi Pembangunan Bendungan Matenggeng}

Sejak tahun 1976 gagasan proyek ini sudah diketahui warga. Asal usul ide pendirian waduk ini sudah ada sejak zaman kolonial Belanda sehingga secara kultur dan turun temurun berita proyek ini sudah dipahami oleh warga. Begitu pula ketika rencana proyek ini mulai digulirkan sejak tahun 2012 oleh pemerintah pusat, maka harapan dan penasaran warga akan realisasi proyek ini semakin tinggi. Wargapun pada dasarnya sudah menyepakati proyek ini mengingat manfaat yang diberikan juga besar.

Masalah krusial dalam tahapan selanjutnya adalah proses pembebasan lahan yang lebih menyangkut keadilan dan kewajaran nilai aset warga terdampak. Khusus di Desa Matengeng terdapat 637 KK atau 2000 jiwa yang harus pindah tetapi dalam desa yang sama.
Masyarakat menyayangkan cara kerja tim pusat yang terkesan tertutup dan sembunyi-sembunyi. Bahkan terkesan BBWS sifatnya hanya informasi bukan sosialisasi karena tidak ada dialog sama sekali. Akibatnya ada beberapa isu penting yang pemahamannya simpangsiur sebagai contoh tawaran harga dari BBWS dengan harga yang sangat murah dari harapan rakyat. Mereka tidak tahu darimana muncul hitungan aset versi pemerintah seperti itu dan mereka juga tidak memahami logika kami mengajukan nilai aset yang berbeda. Menurut pemerintah desa terdapat tim penilai yang terdiri dari: (a) Pemda Cilacap; (b) Dinas Pekerjaan Umum, (c) Amdal; (d) Pengelolaan Sumber Daya Air (PSDA); (e) Perencanaan Pembangunan Nasional (Pertanahan); (f) BBWS Citandeuy; (g) Dinas Peternakan.

Pada tahun 2013 mulai fokus sosialisasi ke warga khususnya di Desa Matenggeng dan Kecamatan Dayeuhluhur pada umumnya terutama rencana pembukaan akses jalan menuju lokasi proyek. Jalan akses menuju proyek panjanganya $20 \mathrm{Km}$ yang melewati lokasi tanah negara (dalam pengelolaaan PTPN IX) dan masyarakat. Dalam rencana proyek ini seharusnya pembebasan tanah untuk akses dilakukan tahun 2013 dan pengerjaan pembuatan akses tahun 2014. Tahap selanjutnya adalah penetapan lokasi. Menurut rencana seharusnya tahun ini sudah dilakukan penentuan pembebasan tanah akses jalan sejauh $20 \mathrm{Km}$. Tahun 2014 adalah tahap pembebasan lahan di lokasi proyek beserta kesepakatan ganti untung yang dijanjikan pemerintah.

Namun kenyataanya, target tahun 2013 tidak tercapai. Pembebasan lahan tersendat terutama tanah warga yang tak kunjung menemui kesepakatan. Pemerintah baru berhasil bersepakat pembebasan lahan Perhutani. Hal ini sangat lumrah karena sebagai BUMN yang dimiliki pemerintah maka negosiasi pembebasannya tidak sulit karena lahan sudah otomatis milik negara. Berbeda dengan tanah warga sebagai hak milik pribadi. Munculnya harga dua juta per meter di Desa Matenggeng adalah salah satu masalah berat tersebut. Warga menyebut tim pusat memilih bergerak diam-diam untuk 
mengetahui nilai real aset warga terdampak. Pemerintah menghindar membicarakannya dalam forum terbuka dan partisipatif. Warga menginginkan sosialisasi, harus bersifat terbuka untuk seluruh warga terdampak bukan hanya pemerintah desa dan tokoh masyarakat. Hal ini penting karena menghindari konflik antarwarga dan menghindari munculnya kelompok calo yang mengklaim aspirasi warga dan memprovokasi pemerintah.

Pemerintah desa menyesalkan ketika tim ini terbentuk hingga saat ini tidak ada surat keputusan yang menyatakan keterlibatan resmi pemerintah desa dalam tim penilai aset warga dampak proyek ini. Mengapa dipandang penting adanya wakil desa yang terlibat resmi dalam tim pembebasan lahan? Karena warga memiliki pengalaman buruk ketika ada enam orang yang bertindak sebagai calo tanah ketika proyek ini digerakkan. Sekarang warga berhati-hati terhadap kemungkinan kejadian serupa. Keenam orang tersebut sudah diberi sanksi yakni dipecat dari kantornya. Persoalan ini yang merisaukan bagi pemeritnah desa terutama dalam mengawal aspirasi desa dalam pembuatan keputusan di tingkat tim penilai tadi. Selain itu warga juga telah membuat pernyataan permohonan mengenai berbagai kebijakan lanjutan yang harus diakomodir bagi warga yang terdampak proyek ini. Ada delapan tuntutan yang tertuang dalam surat atas nama pemerintah desa yang ditujukan kepada pemerintah kabupaten, provinsi, dan pemerintah pusat.

Terhitung sejak tahun 2012 sampai 2014 sudah 12 kali tim pusat datang ke lokasi mengurus proyek ini. Adapun beberapa agendanya: (a) Penetapan lokasi. (b) Sertifikasi lokasi. (c) Bentuk ganti rugi (untung). Pemerintah kecamatan dan desa selalu berada pada posisi dilematis karena selalu mudah dituduh perpanjangan tangan pemerintah pusat bukan bagian dari perjuangan warga. Isu-isu miring bahwa dana sudah diberikan kepada kades dan camat karena telah ada kesepakatan. Ini yang membuat aparatur terbebani membicarakan proyek ini jika tidak didukung kejelasan sikap dari pemerintah daerah dan pusat. Warga
Desa Matengeng berkeras mengambil sikap bahwa siapapun yang menjadi pelaksana proyek tidak akan diberi izin oleh warga jika tidak ada kejelasan dan kesepakatan syaratsyaratnya. Supaya memenuhi rasa keadilan dan menguntungkan warga yang terdampak, mengakomodir lapangan kerja bagi warga setempat di lokasi proyek, kemudian proses perumusan kesepakatan itu harus melibatkan pemerintah desa.

\section{Proses Pembebasan Lahan}

Proses pembebasan terhadap lahan warga akan mengacu pada Peraturan Menteri Pekerjaan Umum Nomor 3 Tahun 2009, tentang Rekayasa Sosial Bendungan dengan beberapa rincian prinsip. Memrakarsai dan memfasilitasi pembentukan forum rembuk masyarakat yang terdiri dari tokoh masyarakat baik formal maupun informal. Kelompok-kelompok masyarakat dan masyarakat yang terkena dampak langsung untuk membahas: (1) Sosialisasi tata letak bendungan dan wilayah genangan bendungan, pembebasan lahan dan pemindahan penduduk. Setelah melakukan musyawarah membahas tata letak dan wilayah genangan bendungan tercapai kesepakatan dan pembangunan fisik. (2) Musyawarah dalam hal membahas ganti untung akan dilakukan secara intensif. Hal ini dikarenakan untuk mendapatkan kesepakatan di dalam penetapan nilai ganti untung tidak dapat dilakukan dengan hanya sekali pertemuan rembuk. Masyarakat akan memahami dan memiliki komitmen menyukseskan program ini jika dilakukan dialog yang rutin dan mendalam.

Menurut Kepala Bidang Pengelolaan Sumber Daya Air Dinas Bina Marga SDA dan ESDM, Saeful Hidayat, bahwa proses pembebasan lahan ini justru jauh dari rencana proyek. Sebagaimana dikutip berita, pemerintah menyatakan proyek ini dipastikan tidak dapat berjalan sesuai jadwal karena antara masyarakat dan pemerintah belum menemukan kesepakatan nilai ganti untung tanah. Harga yang ditawarkan warga tiga kali lipat dari nilai taksiran tim penilai pemerintah. Berhubung tidak ditemukannya kata sepakat maka dalam batas waktu yang telah ditentukan dana yang telah disiapkan 
pemerintah pusat dikembalikan ke kas negara. Mengingat dana tersebut dianggarkan pada APBN 2013.

\section{Deskripsi Pemberdayaan Ekonomi Masyarakat}

Terdapat beberapa usulan warga terdampak dalam mengembalikan dan meningkatkan kesejahteraan mereka terutama ketika proyek ini telah berjalan. Poin tuntutan itu telah dituangkan dalam pernyataan sikap resmi warga kepada pemerintah. Salah satu yang diminta warga adalah adanya akomodasi dan perlindungan bagi warga agar mudah membuka usaha di sekitar waduk nantinya. Jika waduk menjadi lokasi wisata alam dan kuliner maka warga terdampak yang diutamakan membuka usaha seperti itu di sekitar waduk.

Tabel 1

Matrik Identifikasi dan Analisis Hasil Penelitian

\section{No Identifikasi Masalah \\ Potensi \\ Analisis Solusi}

1. Hanya sebagian masyarakat (1) Masyarakat sebetulnya sudah Memerlukan kegiatan sosialisasi secara saja yang mengetahui adanya mengetahui cerita/informasi akan komprehensif dan intensif serta konkrit rencana pembangunan adanya pembangunan Bendungan tentang proses pembangunan Bendungan Bendungan Matenggeng matenggeng secara turun temurun Matenggeng yang difasilitasi oleh terutama yang terkena dari orang tuanya. pemerintah desa, kecamatan dan dampak relokasi lahan (2) Proses sosialisasi bisa saja kabupaten.

pertanian, rumah, dan tanah. dilakukan oleh desa, kadus, RW dan RT baik melalui pertemuan rutin ataupun informal.

2. Masih belum adanya (1) Masyarakat sebetulnya sudah (1) Mengagendakan pelaksanaan kegiatan kesepakatan harga siap/bersedia dan menunggu dialog terbuka antara masyarakat dengan penggantian lahan pertanian, kepastian untuk negosiasi atau dialog pihak terkait yang difasilitasi oleh rumah dan tanah terutama tentang kesepakatan harga dengan pemerintah desa, kecamatan dan dengan desa tetangga. prinsip ganti untung bukan ganti rugi. kabupaten.

Berlarut-larutnya proses (2) Masyarakat Desa Dayeuhluhur (2) Khususnya pihak terkait harus pembangunan Bendungan sebetulnya siap dengan harga proaktif melakukan agenda dialog. Matenggeng. penggantian yang lebih (3) Membentuk tim negosiator di tingkat rasional/rendah atau tidak berlebihan. desa untuk memediasi dengan desa lain Tinggal mengakomodir usulan dan atau pemerintah dan menjadi sumber kesepakatan dengan desa lainnya. informasi bagi warga masyarakat.

3. Potensi konflik terselubung (1) Masyarakat sudah membuka diri (1) Mengagendakan pelaksanaan kegiatan dan konflik terbuka atas untuk siap dan menunggu untuk dialog terbuka antara masyarakat dengan kecurigaan dana penggantian berdialog membahas permasalahan pihak terkait yang difasilitasi oleh yang tidak ransparan atau penggantian lahan. pemerintah desa, kecamatan dan masuk ke rekening kepala (2) Mayarakat menahan diri dan kabupaten.

desa dan kepala kecamatan. belum sepenuhnya percaya terhadap (2) Membentuk tim negosiator resmi di rumor/isu dana masuk ke rekening tingkat desa untuk memediasi dengan kepala desa atau kepala kecamatan. desa lain atau pemerintah dan menjadi sumber informasi bagi warga masyarakat.

4. Masyarakat sudah apriori, (1) Masyarakat sebetulnya sudah (1) Perlu adanya pendekatan khusus yang menaruh kecurigaan dan siap/bersedia dan menunggu persuatif kepada para pemangku cenderung emosional (kesal) kepastian untuk negosiasi/dialog kepentingan

atas berlarutnya proses tentang kesepakatan harga dengan (2) Membentuk Forum dialogis negosiasi dan ketidakpastian prinsip ganti untung bukan ganti rugi Sarasehan yang bersifat informal untuk harga ganti untung. $\quad$ (2) Masyarakat Desa Dayeuhluhur menyepakati ganti untung dilakukan sebetulnya siap dengan harga secara bertahap, Supaya ada kesepakatan penggantian yang lebih bersama tentang harga ganti untung rasional/rendah atau tidak berlebihan. kompak dan bisa menjadi win win Tinggal mengakomodir dengan desa solution atau semua untung tidak ada lainnya. yang dirugikan antara pemerintah dan pihak masyarakat.

5. Belum terjalin komunikasi, (1) Ada delapan desa yang terkena (1) Mengagendakan pelaksanaan kegiatan koordinasi dan kekompakan dampak pembangunan bisa dialog terbuka antara masyarakat dengan 


\section{No Identifikasi Masalah}

\section{Potensi}

Analisis Solusi

antardesa di Dayeuhluhur.

diakomodir usulan untuk diambil) pihak terkait yang difasilitasi oleh kemufakatan bersama. pemerintah desa, kecamatan dan (2 Masyarakat sudah sangat terbuka, kabupaten.

siap, menunggu dan menyetujui (2) Membentuk tim mediasi resmi di adanya pembangunan Bendungan tingkat desa untuk memediasi dengan Matenggeng. desa lain atau pemerintah.

6. Belum ada kepastian realisasi Masyarakat sebetulnya sudah (1) Mengagendakan pelaksanaan kegiatan proses pembangunan siap/bersedia dan menunggu dialog terbuka antara masyarakat dengan Bendungan Matenggeng. kepastian untuk negosiasi/dialog pihak terkait yang difasilitasi oleh tentang kesepakatan harga dengan pemerintah desa, kecamatan dan prinsip ganti untung . kabupaten.

(2) Pihak terkait harus proaktif melakukan agenda dialog.

(3) Membentuk tim mediasi independen untuk memediasi antar desa dan dengan pemerintah serta menjadi sumber informasi bagi warga masyarakat.

Sumber : Analisis Hasil Penelitian

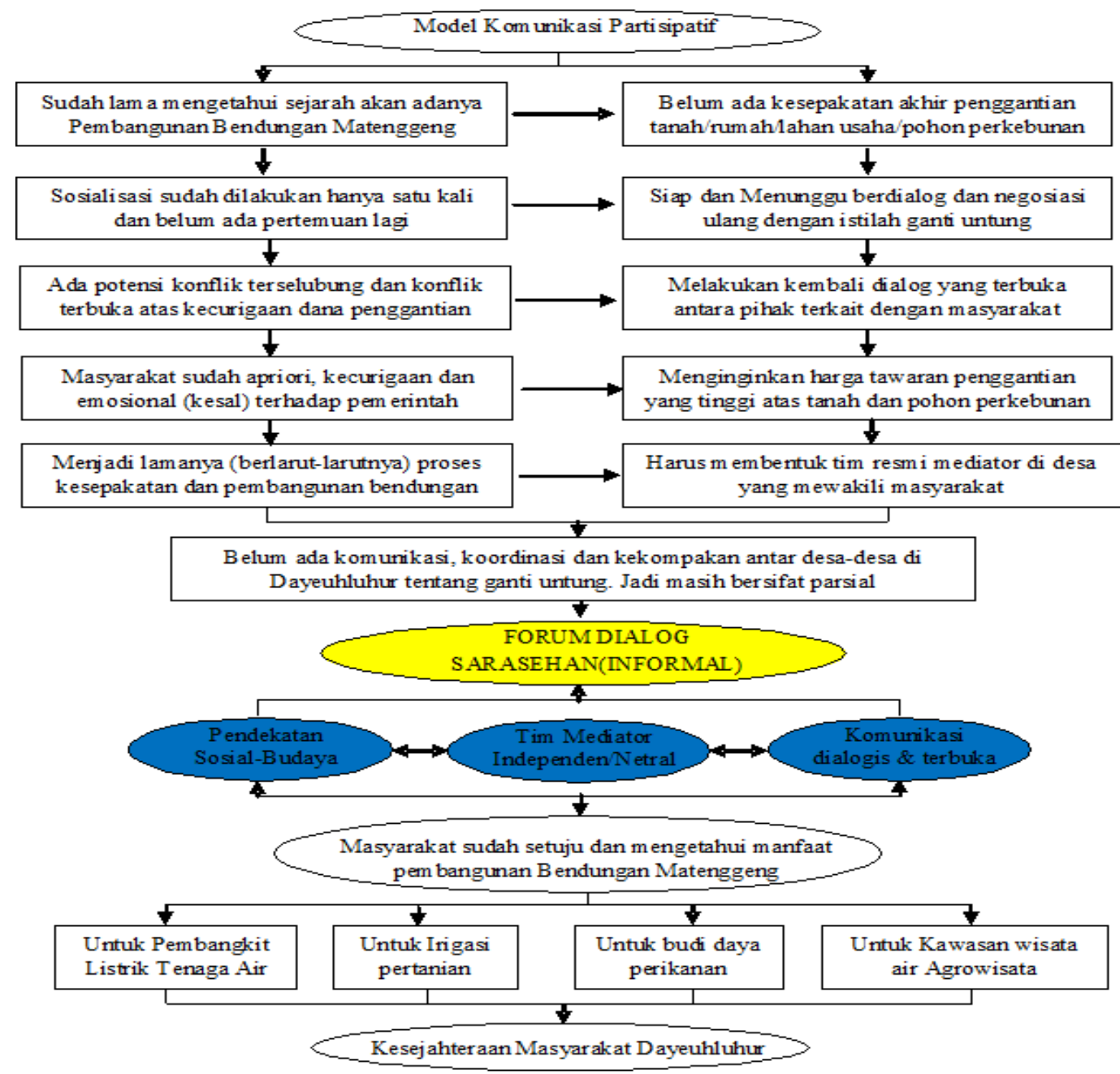

Gambar 2

Model Komunikasi Partisipatif 
Warga juga mengritik cara pemerintah menilai aset mereka terutama tanaman perkebunan seperti pohon karet, manggis, petai, kelapa. Warga meminta bukan hanya tanahnya yang dinilai tetapi juga tanaman yang tumbuh di atasnya. Mengingat tanaman tersebut adalah investasi jangka panjang dengan nilai ekonomi yang tinggi. Sebagai contoh: tanaman karet butuh dipelihara empat sampai lima tahun baru dapat dipetik hasilnya dengan nilai jutaan setiap kali panen. Begitu pula manggis dan petai, hasil panennya mahal dan usia tanamanya lama. Jika semua ini tidak dihitung warga pasti sangat dirugikan. Contoh usulan warga mengusulkan manggis Rp700.000/pohon. Warga juga meminta pelatihan dan bantuan modal usaha perikanan air tawar yang ada di waduk.

Hal tersebut dapat diilustrasikan pada model komunikasi partisipatif masyarakat dalam pembangunan Bendungan Matenggeng seperti pada gambar 2 .

\section{PENUTUP}

\section{Simpulan}

Bendungan Matenggeng sebagai solusi persoalan air dan banjir di wilayah Jawa Tengah, Kabupaten Cilacap Barat serta sebagian wilayah Jabar, yang sudah digagas sejak 1969 lalu, bahkan konsultan dari Amerika Serikat telah dua kali melaksanakan survei terhadap rencana pembangunan Bendungan Matenggeng yakni pada 1969 dan 1989, namun belum ada kelanjutan. Akhirnya direalisasikan kembali dengan masuk pada Masterplan P3EI 2011-2025 dan tahun 2013 sedang dirancang perjanjian kerjasama antara Kabupaten Cilacap, Provinsi Jawa Tengah, Kabupaten Ciamis, dan Kabupaten Kuningan, Provinsi Jawa Barat terkait komitmen pembebasan lahan dan pembagian (sharing) pendanaan anggaran Bendungan Matenggeng, dibahas dalam Rapat Tim Teknis Penilai analisis mengenai dampak lingkungan (AMDAL) Pusat Rencana Pembangunan Bendungan Matenggeng di Wilayah Kabupaten Cilacap, Provinsi Jawa Tengah dan Kabupaten Ciamis, Provinsi Jawa Barat pada, Selasa 19 Februari 2013. Rapat tersebut dipimpin oleh Asisten Deputi Kajian Dampak
Lingkungan, Kementerian Lingkungan Hidup, dengan peserta dari jajaran pemerintahan sebagai stakeholders dari Kabupaten Cilacap dan Kabupaten Ciamis dan Kabupaten Kuningan, yang menghasilkan manfaat sebagai berikut: (i) Untuk penyediaan air irigasi pertanian di daerah hilir dan menjamin tersedianya air irigasi untuk lahan seluas 27.927 ha di empat kabupaten/kota, yaitu Kabupaten Cilacap, Kabupaten Ciamis, Kabupaten Kuningan, dan Kota Banjar; (ii) Menyediakan pasokan air baku, terutama pada musim kemarau untuk pengembangan air baku di empat kecamatan di Provinsi Jawa Barat dan Provinsi Jawa Tengah; (iii) Mengurangi besarnya banjir ke bagian hilir sebesar $65 \%$. Adapun manfaat utamanya bagi masyarakat atau penerima manfaat (benefeciaries) di lingkunagan sekitar Bendungan, terutama Kabupaten Cilacap, Kabupaten Ciamis, Kabupaten Kuningan, dan Kota Banjar dalam bentuk ketersediaan air baku, pengairan (irigasi), dan reduksi debit banjir.

Masyarakat sudah sejak lama mengetahui adanya rencana pembangunan Bendungan Matenggeng yang informasinya didapatkan dari orang tua sejak tahun 1960an. Kemudian proses realisasi pembangunan Bendungan Matenggeng mulai tahun 2013 dan sudah mengetahui fungsi dan kemanfaatan Bendungan Matenggeng yaitu untuk Pembangkit Listrik Tenaga Air (PLTA), irigasi pertanian dan objek pariwisata serta perkembangan usaha perikanan.

Sebagian mayarakat terutama aparat desa sudah mendapat sosialisasi tentang proses pembangunan Bendungan Matenggeng. Masyarakat setuju dengan adanya pembangunan Bendungan Matenggeng yang akan mendatangkan dan meningkatkan kesejahteraan bagi warga masyarakat. Kemudian masyarakat sudah menunggu realisasi proses pembangunan Bendungan Matenggeng dan mengharapkan secepatnya di bangun dan siap menunggu untuk berdialog atau negosiasi ulang tentang realisasi proses penggantian lahan untuk pembangunan Bendungan Matenggeng. 
Berdasarkan hasil telaah komunikasi pembangunan partisipatif, bahwa masyarakat merasa cemas dan khawatir akan ketidakpastian realisasi proses pembangunan Bendungan Matenggeng. Sehingga masyarakat tidak berani untuk membangun atau merenovasi tempat tingggal atau mengolah lagi lahan usaha pertanian dan perkebunananya, karena khawatir tergusur proses pembangunan bendungan.

\section{Saran}

Perlu segera ditindaklanjuti kepastian pembangunan bendungan Matenggeng supaya tidak menciptakan kebingungan dan kekhawatiran khususnya bagi masyarakat yang terkena dampak langsung atas lahan, tanah, rumah, dan sumber penghasilan dengan melakukan komunikasi pembangunan partisipatif antara pihak pemerintah dan masyarakat untuk membahas proses pembangunan dan ganti untung yang disepakati bersama.

Pemerintah perlu lebih pro aktif melakukan komunikasi pembangunan partisipatif yang lebih humanis dan kooperatif dengan membuat agenda pertemuan atau dialog dengan warga masyarakat secara terbuka dan harmonis.

Model komunikasi pembangunan partisipatif dengan membentuk Forum Dialog Sarasehan yang bersifat informal yang berbasis pendekatan sosial budaya dari masyarakat Dayeuhluhur, komunikasi yang dialogis dan terbuka. Hal ini diperlukan supaya proses negosiasi dan dialog antara masyarakat dan pemerintah tidak dalam situasi berhadapan atau dominan nuansa perselisihan atau konflik kepentingan. Tetapi dialog diselenggarakan dengan penuh kekeluargaan dan musyawarah.

\section{DAFTAR PUSTAKA}

\section{Buku:}

Adi, I.R. (2003). Pembardayaan, Pengembangan Masyarakat danIntervensi Komunikasi: Pengantar pada Pemikiran dan Pendekatan
Praktis. Jakarta: Fakultas Ekonomi Universitas Indonesia.

Adisasmita, R. (2006). Membangun Desa Partisipatif. Yogyakarta: Graha Ilmu.

Dasgupta, S. (2009). Sonagachi Project: A Case-Study Set India. McPhail TL, editor. Development Communication: Reframing The Role of Media. Malden (US), Oxford (GB): Blackwell Publishing Ltd.

Hasim dan Remiswal. (2009). Community Development Berbasis Ekosistem: Sebuah Alternatif Pengembangan Masyarakat. Jakarta: Diadit Media.

Mardikanto, T. (2010). Komunikasi Pembangunan : Acuan Bagi Akademisi, Praktisi, dan Peminat Komunikasi Pembangunan. Surakarta (ID): UPT Penerbitan dan Pencetakan UNS Pr.

Lubis, D. (2010). Komunikasi dan Pembangunan. Di dalam : Hubeis AVS, editor. Dasar-Dasar Komunikasi. Bogor (ID): Sains KPM IPB Pr.

McPhail, T.L. (2009). United Nations and Specialized Agencies. McPhail TL, editor. Development Communication: Reframing The Role of Media. Malden (US), Oxford (GB): Blackwell Publishing Ltd.

Miles MB, Huberman AM. (2007). Analisis Data Kualitatif. Rohidi TR, penerjemah. Jakarta (ID): UI Press. Terjemahan: Qualitative Data Analysis.

Mikkelsen, B. (2011). Metode Penelitian Partisipatoris dan Upaya Pemberdayaan : Panduan Bagi Praktisi Lapangan. Jakarta: Yayasan Obor Indonesia.

Moeliono, Ilya. (2003). Memadukan Kepentingan Memenangkan Kehidupan, buku acuan Metodologi Pengelolaan Sengketa Sumberdaya Alam. Bandung: Driyamedia.

Nair, K.S dan White, S.A. (2004). Participatory Development as Cultural Renewal. White SA, Nair KS, Ascroft J, editor. Participatory Communication: Working for Change and Development. New Delhi (IN), Thousand Oaks (US), London (GB): Sage Publication. 
Porras, L.E dan Steeves, H.L. (2009). Feminism in a Post-Development Age : McPhail, Thomas L, editor. Development Communication: Reframing The Role of The Media. Malden (US), Oxford (GB): Blackwell Publishing Ltd.

Subyantoro A dan Suwanto FX. (2007). Metode Penelitian dan Teknik Penelitian Sosial. Yogyakarta: Penerbit Andi.

\section{Jurnal:}

Alam, A, Syamsu. (2012). Analisis Kebijakan Sosial di Perkotaan sebagai Sebuah Kajian Implementatif. Jurnal Ilmiah Ilmu Pemerintahan. Vol 1. No 3, Juni 2012, hal. 78-92.
Internet:

Soekotjo, Tri Susilo. (2013a). Gubernur Jateng Temui Warga Matenggeng, Terkait Pembangunan Waduk. Tersedia dalam <http://www.cilacapkab.go.id>, diakses 4 Maret 2013.

(2013b). Bendung Matenggeng Mulai Dibangun Tahun ini.Tersedia dalam <http://www.suaramerdeka.com>, diakses 26 Februari 2013.

Kurniawan, Herly. (2013). Rencana Pembangunan Bendungan Matenggeng Di Cilacap dan Ciamis untuk Mendukung Sektor Pertanian. Tersedia dalam <http://ditjenbun.deptan.go.id>, diakses 25 Februari 2013. 